\title{
Competitive Interactions Between Neurons Making Axosomatic Contacts in the Leech
}

\author{
Xiaonan Gua and Kenneth J. Muller \\ Department of Physiology and Biophysics, University of Miami School of Medicine, Miami, Florida 33136
}

\begin{abstract}
Axons of lateral nociceptive $(\mathbf{N})$ neurons in leech segmental ganglia wrap certain somata in adjacent ganglia but no somata in their own ganglion. In adults, the $\mathbf{N}$ neurons, which accurately regenerate axosomatic wrappings, can be induced to sprout in their own ganglion and wrap target homologues if the ganglion is isolated by cutting the nerve cord. Manipulations that denervate the new targets without injuring the lateral $\mathbf{N}$ cell, including focal lesions and protease injections into other $\mathbf{N}$ cells, also cause sprouting within 2-4 months. In contrast, cutting the lateral $\mathbf{N}$ cell's axons causes little or no sprouting within the ganglion without denervation. Therefore, denervation rather than injury accounts for sprouting within the ganglion. It is concluded that lateral $\mathbf{N}$ cells can wrap somata in their own ganglion that are homologues of their usual targets, but they are prevented from doing so by axonal wrappings from $\mathbf{N}$ cells in adjacent ganglia.
\end{abstract}

It is critical for neural development and for successful nerve repair that growing neurons connect with only certain targets. One reason neurons select particular types of synaptic targets is an intrinsic matching between cells or cell groups (Gaze, 1970; Landmesser, 1980), but additional mechanisms can operate in target selection. For example, though the initial matching during embryonic development does not rely on functional validation (Harrison, 1904; Rakic, 1976; Harris, 1980), after contacts form, they may shift or be refined by competition between functioning neurons (Hubel et al., 1977). At the neuromuscular junction, this competition is mediated by the target (Grinnell et al., 1979), but less is known about the interactions when neurons are targets, particularly at the level of individual neurons making welldefined connections. While vertebrate and invertebrate neurons appear to share basic mechanisms for growth and target selection, precise connections have been best demonstrated for identified neurons in invertebrates. Thus, in many invertebrates, including the leech, connections are made only between particular neurons or even certain parts of those neurons (Macagno et al., 1973; Kandel, 1976; White et al., 1976; Muller et al.,

\footnotetext{
Received May 15, 1990; revised July 26, 1990; accepted Aug. 1, 1990.

This work was supported by NIH Grant RO1-NS 20607. We thank Drs. Ellen McGlade-McCulloh and Steven R. Young for useful discussions, Ms. Alice Morrissey and Ms. Rose Harris for technical assistance, and Dr. Young and Dr. Sheryl Scott for helpful comments on a draft of the manuscript.

Correspondence should be addressed to Dr. Kenneth J. Muller, Department of Physiology and Biophysics, University of Miami School of Medicine, P.O. Box 016430 , Miami, FL 33101.

a Present address: Department of Biology, B-022, University of California at San Diego, La Jolla, CA 92093.

Copyright (C) 1990 Society for Neuroscience $0270-6474 / 90 / 123814-09 \$ 03.00 / 0$
}

1981; Jacobs et al., 1986). It is not known whether these apparently precise connections are influenced by competition during either their formation or their maintenance.

In the lecch, there is considerablc capacity for faithful repair after nerve injury. For example, the nociceptive (N) mechanosensory neurons will regenerate functional synapses with their usual neuronal targets in adjacent ganglia (Jansen and Nicholls, 1972; Wallace et al., 1977; Elliott and Muller, 1983). While no "errors" have been detected with microelectrode recordings from pairs of cells, it has been impractical to test all possible connections after regeneration. In principle, synapses could instead be examined anatomically, but most synapses between neurons in the leech are made in the complex neuropil at the center of the ganglion, where even with electron microscopy, it is difficult to trace a cell's synaptic contacts. However, the $\mathrm{N}$ cells make a distinctive set of contacts plainly visible with the light microscope; these are axosomatic wrappings of certain other sensory neuron somata by $\mathrm{N}$-cell axons (Muller et al., 1978; French and Muller, 1986). Physiological recordings from the wrapped cells, which are pressure sensory (P), other $\mathrm{N}$, and Lcydig cclls, show that they are postsynaptic, and that the contacts are excitatory. The lateral $\mathrm{N}$ cells ( $l \mathrm{~N}$ cells) wrap only neurons in the 2 ganglia adjacent, anterior and posterior, but not homologous cells in the $l \mathrm{~N}$ cell's own ganglion. The present paper examines this selectivity for targets in adjacent ganglia.

A touchstone for the study was the finding that severed $\mathrm{N}$-cell axons can regenerate axosomatic wrappings around their usual targets (French and Muller, 1986); thus, the selectivity of contacts is basically preserved in the adult. A minor reservation is that 1 cell, normally wrapped only rarely, was wrapped more frequently after regeneration. In some studies, it has been found that repair in the leech may be facilitated by long-surviving distal segments of severed axons (Mason and Muller, 1983); therefore, in experiments in which it is important to ensure the degeneration of axons, it can be useful to inject neurons with a protease (Bowling et al., 1978). Some of the experiments on adult leeches described in the present paper employed this technique and were designed to determine whether $l \mathrm{~N}$ cells can wrap somata in their own ganglia, and if so, why they ordinarily do not.

\section{Materials and Methods}

Maintenance and operations. Leeches (Hirudo medicinalis) were obtained, either directly from Ricarimpex (Audenge, France) or bred in the laboratory (McGlade-McCulloh et al., 1989), fed periodically with bovine blood, and maintained at $18^{\circ} \mathrm{C}$ in artificial spring water (see Appendix C of Muller et al., 1981). When connectives were to be severed, animals were anesthetized with $8 \%$ ethanol in spring water, and small incisions were made in the ventral midbody region superficial to the nerve cord, typically at segmental ganglia 9 (G9) and 13 (G13). 
Connectives were cut, either singly or in pairs, on both sides of the ganglion after the surrounding blood sinus was opened. For other operations, in which identified cells were to be killed by protease injection, animals were anesthetized for $25 \mathrm{~min}$ in $15 \mathrm{~mm}$ chlorobutanol dissolved in artificial spring water, ganglia were exposed in a bath containing leech saline $\left(115 \mathrm{~mm} \mathrm{NaCl}, 4 \mathrm{~mm} \mathrm{KCl}, 2 \mathrm{~mm} \mathrm{CaCl}_{2}\right.$, and $10 \mathrm{~mm}$ Tris maleate, adjusted to $\mathrm{pH} 7.4$ with $\mathrm{NaOH}$ ), and particular $\mathrm{N}$ cells were injected with protease (Sigma, Type VIII; $0.2 \%$ in $0.2 \mathrm{M} \mathrm{KCl}$ containing $0.4 \%$ Fast Green FCF dye) under pressure (Bowling et al., 1978). Protease injection destroys the entire neuron without damaging other cells or axons in the vicinity of the killed neuron (Bowling et al., 1978; Scott and Muller, 1980). Animals were allowed to recover in leech saline 1 or $2 \mathrm{~d}$, then transferred to artificial spring water at $16^{\circ} \mathrm{C}$.

Intracellular labeling. Lateral $\mathrm{N}$ cells in ganglia denervated by severing connectives or by killing cells with protease were examined after periods up to more than $1 \mathrm{yr}$ after the operation, though in most cases, the interval was from 2 to 6 months. To view each of the $2 l \mathrm{~N}$ cells in a single ganglion separately and in detail, onc cell was usually injected with $0.1 \mathrm{M}$ 6-carboxyfluorescein (6-CF) under pressure and viewed live, before fixation, while the other was injected with HRP (Sigma, Type $\mathrm{VI} ; 2 \%$ in $0.2 \mathrm{M} \mathrm{KCl}$ and $0.2 \%$ Fast Green FCF) and viewed after fixation. For these studies of sprouting, HRP was injected $1 \mathrm{~d}$ before fixation to ensure dense staining throughout the cell within the ganglion. To determine the extent of typical axonal projections into adjacent ganglia, $\mathrm{N}$ cells were injected with HRP $2 \mathrm{~d}$ and again $1 \mathrm{~d}$ before fixation (Elliott and Muller, 1983). Epifluorescence optics (Zeiss filter set 472209 and $10 \times$ Neofluor objective, $0.3 \mathrm{NA}$ ) were used to view briefly the fluorescent axosomatic wrappings. Just before fixation, the pressure (P) cells and medial $\mathbf{N}$ cells, the potential targets, were typically marked by intracellular injection of 4\% Procion navy blue dye after being identified electrophysiologically; this permitted unequivocal identification of $P$ and Leydig cells and of touch sensory $(T)$ and $\mathrm{N}$ cells in whole-mounts of fixed ganglia (French and Muller, 1986). Cells from control and experimental leeches were labeled in the same manner.

Preparations were fixed for $30 \mathrm{~min}$ at room temperature in $1.6 \%$ glutaraldehyde, $0.8 \%$ paraformaldehyde, and $5 \mathrm{~mm} \mathrm{CaCl}_{2}$ in $0.1 \mathrm{M}$ sodium cacodylate buffer ( $\mathrm{pH}, 7.4$; Muller and Carbonetto, 1979). Tissue was then processed with $3,3^{\prime}$-diaminobenzidine and $\mathrm{H}_{2} \mathrm{O}_{2}$ as substrates for the HRP, and mounted whole as previously described (Muller and McMahan, 1976). Contrast was enhanced and depth of focus reduced by viewing preparations using a $40 \times$ water immersion objective $(0.75$ NA) with Nomarski interference optics.

Electron microscopy. For electron microscopy, tissue was prepared as above, except that fixed tissue was postfixed with osmium and embedded in Epon 812 (Muller and McMahan, 1976). Sections $2 \mu \mathrm{m}$ thick were cut until axosomatic wrappings werc visible. Then, thin sections were cut, stained with lead citrate, and viewed with a Philips EM300 electron microscope.

\section{Results}

\section{Distribution of axosomatic contacts by lateral $N$ cells}

$\mathrm{N}$-cell axons project anteriorly and posteriorly to neighboring ganglia, where they wrap the somata of the $\mathbf{N}$ and $\mathbf{P}$ mechanosensory neurons ipsilaterally and, to a lesser extent, contralaterally (Figs. 1, 2). The $l \mathrm{~N}$ cells wrap more somata than do medial $N(m N)$ cells (French and Muller, 1986), but no distinction was made previously between ipsilateral and contralateral wrappings, nor was there a systematic search for the presence of axosomatic wrappings in the $\mathrm{N}$ cells' own ganglion. Figure 2 confirms the previous results for the $I \mathrm{~N}$ cell and also shows that the majority, but not all, of its wrappings in the 2 neighboring ganglia are ipsilateral. In anterior adjacent ganglia, 27 of $30 \mathrm{lN}$ cells $(90 \%)$ made axosomatic contacts, while 30 of $32 / \mathrm{N}$ cells examined $(94 \%)$ wrapped somata in posterior ganglia. The average numbers of wrappings each $l \mathrm{~N}$ cell made in anterior and posterior adjacent ganglia were 2.9 and 3.2, respectively. Only once did one of the $32 l \mathrm{~N}$ cells wrap the soma of any neuron within its own ganglion, and that was a lateral $\mathrm{P}(l \mathrm{P})$ cell on the contralateral side. French and Muller (1986) reported no wrappings within the $l \mathrm{~N}$ cells' own ganglion.

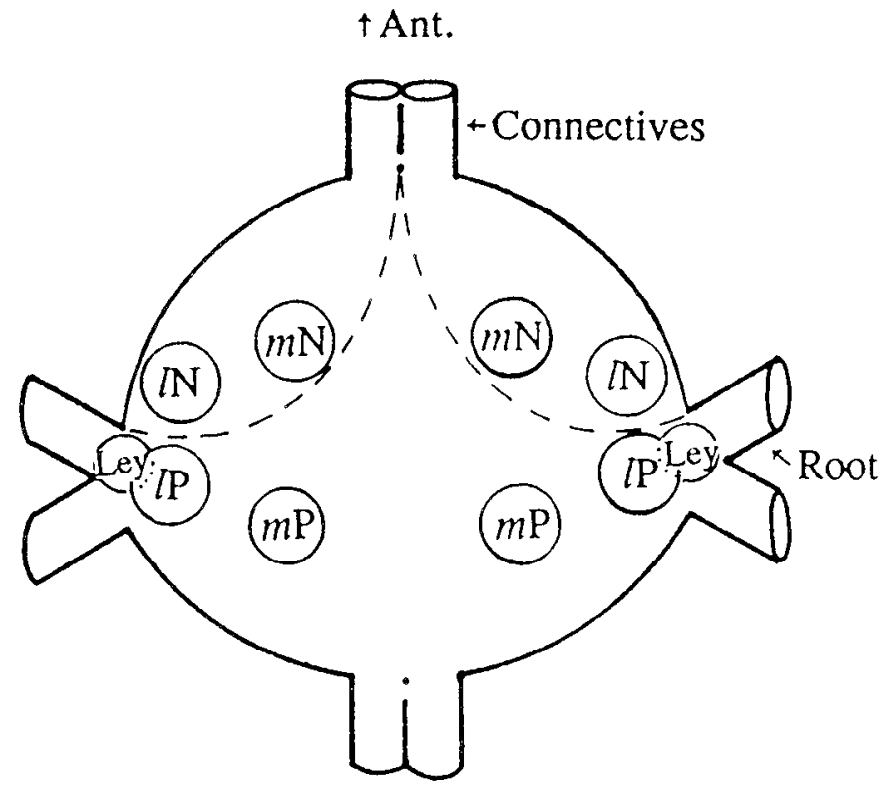

Figure 1. Diagram of ventral aspect of ganglion showing approximate locations of somata ordinarily wrapped by axons of $l \mathrm{~N}$ cell. Wrapped somata are usually situated only in other ganglia, anterior and posterior to the $l \mathrm{~N}$ cell. The axosomatic targets are the $m P, l P, m N, l N$, and Leydig (Ley) cells. Ant, anterior.

The $l \mathrm{~N}$ cells wrapped the somata of only certain types of cells, and in that sense, they were selective. Combining results from anterior and posterior ganglia, $40 \%$ of the total number of wrappings wcre of $\mathrm{N}$ cells, with $17 \% \mathrm{mN}$ cells and $23 \% / \mathrm{N}$ cells. The $P$ cells accounted for $49 \%$ of wrappings, with $28 \%$ on medial $P$ $(m \mathrm{P})$ and $21 \%$ on $l \mathrm{P}$ somata. The Leydig cell, a cell usually situated next to the $l P$ cell, received $11 \%$ of the axosomatic contacts (Fig. 2). Contralateral N, P, and Leydig cells were also wrapped, but they accounted for only $16 \%$ of all axosomatic contacts. French and Muller (1986) examined $l \mathrm{~N}$ cells in 54 ganglia and, in addition to $\mathrm{N}, \mathrm{P}$, and Leydig cells, once saw a small cell of unknown identity along the posterolateral margin of the ganglion that also received an axosomatic contact from an $\mathrm{N}$ cell. An unusual cell was seen once in the 62 ganglia examined in the present study, and it was a small cell in the same posterolateral location.

\section{Lateral $N$ cells can sprout axosomatic contacts within surgically isolated ganglia}

Experiments in this section were designed to tcst the basis for the $l \mathrm{~N}$ cell choosing to wrap only somata in other ganglia. Perhaps the $l \mathrm{~N}$ cells might sprout axosomatic contacts within their own ganglion if they were prevented from making their usual contacts in other ganglia, or if target homologues in their own ganglion were made more attractive through denervation, or if a combination of the 2 occurred. This was done by isolating a ganglion from its neighbors by cutting both anterior and posterior connectives (Fig. 3). The severed axons were unable to regenerate across the transection because the ends of the muscular connectives pulled away from each other. This type of operation had previously been shown to produce marked changes not only in the physiology of the isolated ganglion, but also elsewhere up and down the nerve cord (Jansen et al., 1974).

Within 2 months after ganglion isolations, most $I N$ cells had sprouted axosomatic contacts within their ganglion, wrapping 
Figure 2. Proportions of somata ordinarily wrapped by axons of $l \mathrm{~N}$ cell. Locations and identities of the wrapped cells, situated only in anterior and posterior ganglia, are indicated in Figure 1. The ordinate in the graphs indicates the average incidence, expressed as a percentage, with which each $l \mathrm{~N}$ cell wraps somata of particular cells in adjacent ganglia; $n$ is the number of $l \mathrm{~N}$ cells injected and examined. Wrapped cells indicated in the graph are the $m P, I P, m N$, $l N$, and Leydig (Ley) cells as in Figure 1. Fewer contralateral than ipsilateral cells are wrapped. The hatched circles in the diagram on the left represent cells designated in the bar graphs; the injected $l \mathrm{~N}$ cell is black. Less hatching on contralateral cells represents a lower incidence of wrapping. Open circles are target homologues, not wrapped, in the $l \mathrm{~N}$ cell's own ganglion. The other $(O t h)$ cell wrapped appeared to be that described previously, located at the posterolateral margin of the ganglion (French and Muller, 1986).
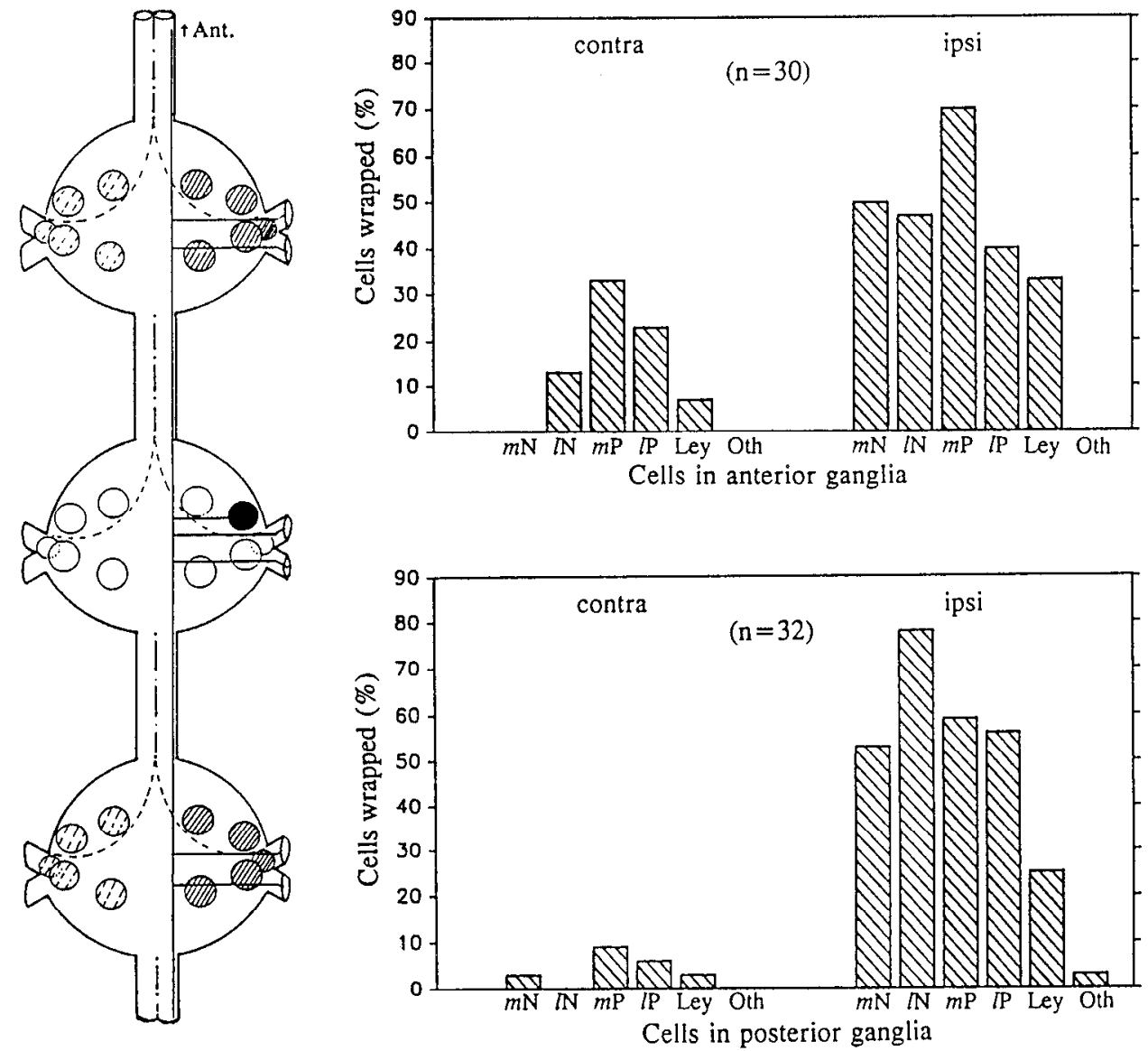

Swellings or varicosities were present at intervals along the branches, suggesting they might be presynaptic sites, but most of the varicosities were smaller than the $5-\mu \mathrm{m}$ enlargements typical of synapses in the neuropil. Electron micrographs of HRP-filled sprouted axons showed that they were mostly separated from the target soma by glia but, in places, lie directly apposed to the soma. Figure 5 illustrates one region of apposition near a site of neurofilament attachment to the soma membrane (Pumplin and Muller, 1983), though such attachment sites (Fig. 4). Typically, the $\mathbb{N}$ ax basket of processes over the surface of the target cell's soma. an average of 2.5 wrappings (see also Table 1). Wrapped somata were nearly evenly distributed on both sides of the ganglion. Only N, P, and Leydig cells were wrapped. It is not known whether $I N$ cells wrapped their own somata. The new axosomatic wrappings resembled the established
wrappings in adjacent ganglia (Fig. 4). Typically, the $l \mathrm{~N}$ axon

\begin{tabular}{|c|c|c|c|}
\hline Type of preparation & $\begin{array}{l}\text { Average } \\
\text { number of } \\
\text { wrappings }\end{array}$ & $\begin{array}{l}\text { Percentage } \\
\text { cells } \\
\text { sprouted }\end{array}$ & $N$ \\
\hline \multicolumn{4}{|l|}{ Ganglia fully denervated } \\
\hline Isolated ganglia & 2.5 & 84 & 62 \\
\hline All $8 \mathrm{~N}$ cells killed in anterior and posterior ganglia & 2.5 & 88 & 16 \\
\hline \multicolumn{4}{|l|}{ Ganglia half-denervated } \\
\hline \multicolumn{4}{|l|}{ Single anterior and posterior connectives cut, 1 side } \\
\hline Four $\mathrm{N}$ cells killed in antcrior or posterior ganglia & 0.9 & 50 & 24 \\
\hline Four $l \mathbb{N}$ cells killed in anterior and posterior ganglia & 0.9 & 47 & 15 \\
\hline Four $m \mathrm{~N}$ cells killed in anterior and posterior ganglia & 0.1 & 13 & 8 \\
\hline \multicolumn{4}{|l|}{ Controls } \\
\hline Four Retzius cells killed in anterior and posterior ganglia & 0.1 & 14 & 14 \\
\hline Unoperated, anterior/posterior adjacent ganglia & 3.1 & $90 / 94$ & 62 \\
\hline
\end{tabular}



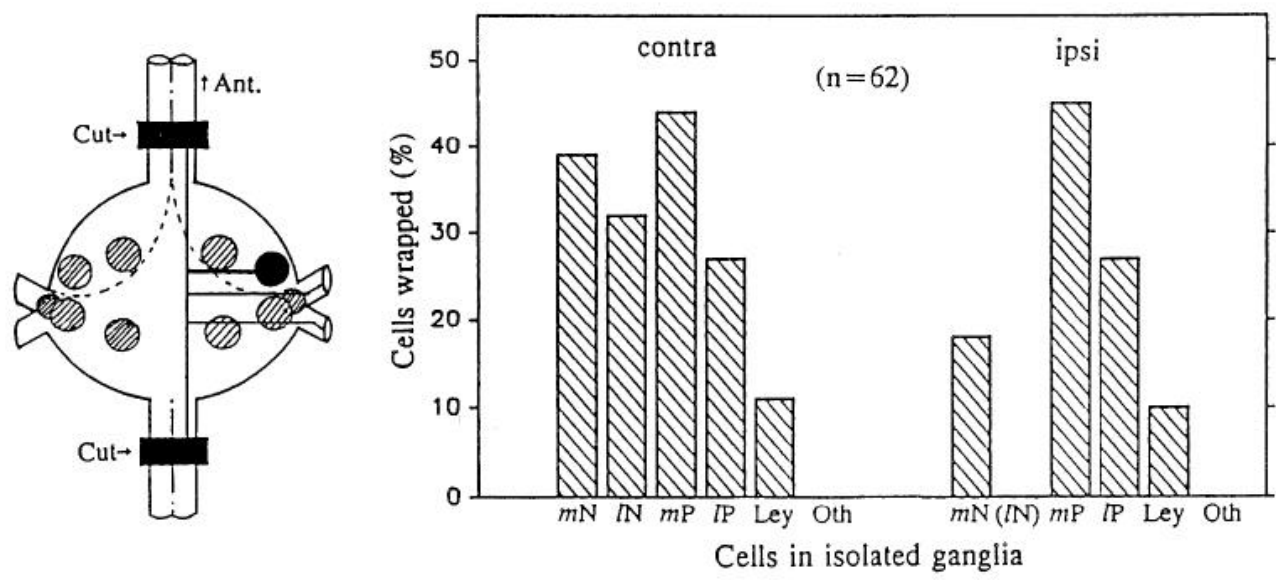

Figure 3. Within isolated ganglia, $l \mathrm{~N}$ cell axons sprouted to wrap homologues of their usual axosomatic targets. Each $l \mathrm{~N}$ cell, examined from 2 to 6 months after cutting both anterior and posterior connectives, wrapped a total of 2.5 cells, on average, distributed on both sides of the ganglion. Sprouting occurred in 29 of 31 ganglia (94\%); 52 of the $62 l \mathrm{~N}$ cells examined (84\%) made up to 8 axosomatic contacts within their ganglion, with a median number of 2 neurons wrapped by individual $l \mathrm{~N}$ cells. It is not known if the $l \mathrm{~N}$ cell axons wrap their own somata $(l N)$. In the diagram on the left, the locations of cuts are shown as solid bars crossing the connectives, the $l \mathrm{~N}$ cell is solid black, and newly wrapped somata are indicated with hatching. Ant, anterior; Ley, Leydig cells; $O t h$, other cells. were not associated with axosomatic contacts. With electron microscopy, the sprouted axosomatic contacts were indistinguishable from those described for normal wrappings, which did not resemble chemical or electrical synapses within the neuropil, but could have been sites of transmitter release (French and Muller, 1986).

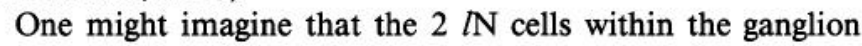
might interact, either in concert to increase the likelihood that a target would be wrapped by both cells or in competition to reduce the likelihood of double wrapping. In fact, in 13 of 31 isolated ganglia (42\%) some targets were wrapped by both $l \mathrm{~N}$ cells. The expected distribution of the wrappings by both $l \mathrm{~N}$ cells, assuming independent wrapping (Fig. 3), is $34 \%$ overall, but an error of $10 \%$ in individual probabilities would place the observed incidence of ganglia with cells doubly wrapped within the error of the calculated incidence. The observed distribution of doubly wrapped cells among a total of 21 was $4(19 \%) m \mathrm{~N}$, $12(57 \%) m \mathrm{P}$, and $5(24 \%) l \mathrm{P}$. These are slightly higher than but comparable to the values predicted from the incidences for individual cells in Figure 3 of $14 \%$ for $m \mathrm{~N}, 40 \%$ for $m \mathrm{P}$, and $15 \%$ for $l \mathrm{P}$, which indicates that sprouted wrappings within the ganglion are probably independent of one another.
Lateral $\mathrm{N}$ cells in ganglia anteriorly and posteriorly adjacent to the isolated ganglion were also examined for axosomatic wrappings made by axons of their own $l \mathrm{~N}$ cells. For such ganglia, only 1 pair of connectives had been cut, while the other pair had not. From 2 to 6 months postoperative, the $l \mathrm{~N}$ cell's axon wrapped somata in the cell's own ganglion in only $7 \%$ of ganglia $(n=28)$. At longer postoperative intervals, the $l \mathrm{~N}$ cells in $30 \%$ of ganglia $(n=33)$ had sprouted axosomatic contacts, but this value was far below the more than $95 \%$ of isolated ganglia in which sprouting was observed.

\section{Cutting only the left anterior and posterior connectives distinguishes effects of injury from denervation}

Although $l \mathrm{~N}$ cells can sprout to wrap certain neurons within their isolated ganglion, it is unclear whether sprouting is triggered by direct injury to the $l \mathrm{~N}$ cell, by denervation of the targets thereby making those targets available to receive new inputs, by a combination of injury and denervation, or by additional effects of surgery, such as target injury, thereby causing the target to release trophic substances or making it receptive to inputs. In the leech and some other organisms, there is evidence both
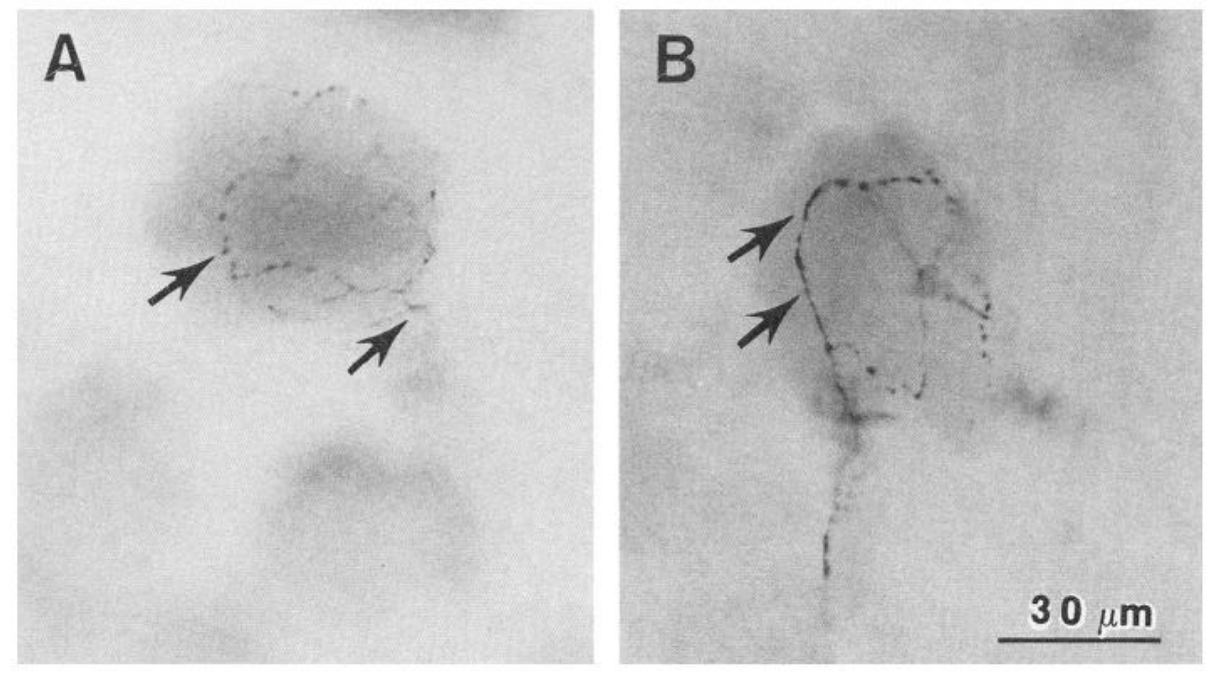

Figure 4. Sprouted axosomatic wrappings in $l \mathbb{N}$ cell's ganglion resemble wrappings in adjacent ganglia. $a, \mathrm{~N}$-cell axons typically wrap certain somata in neighboring ganglia (Fig. 1), including this $\mathrm{P}$ cell. The dark axons of the $I \mathrm{~N}$ cell, injected with HRP, stand out against the blue-stained $P$ cell they wrap. $b$, Within 2 months after the connectives linking the $I \mathrm{~N}$ cell's ganglion with its neighbors were cut, the N cell's axons had wrapped homologues in its own ganglion of its usual targets, including this P cell. Arrows indicate varicosities of the axonal wrappings. 


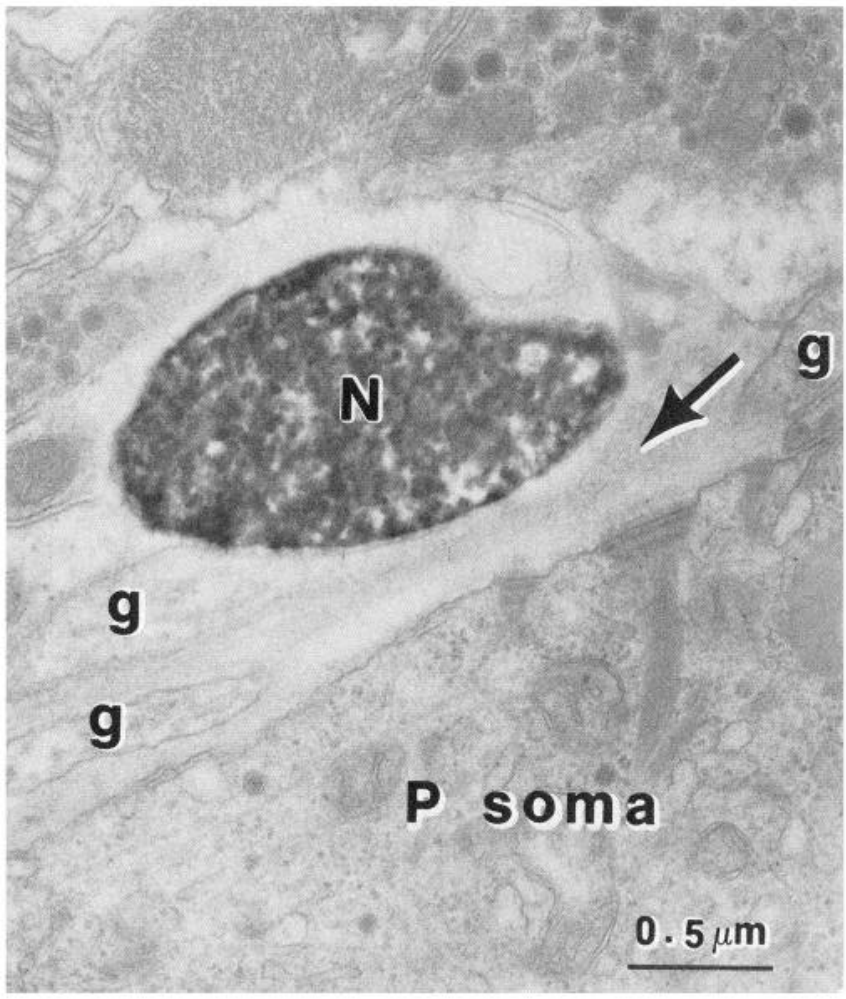

Figure 5. Sprouted axon of $l \mathrm{~N}$ cell $(N)$, filled with HRP, wraps soma of $P$ cell. Most of the P-cell surface is ensheathed by glia $(g)$, but in certain places as in this section at the arrow, the $\mathrm{N}$ and $\mathrm{P}$ cells can be found in proximity without interposed glia. This particular region also happened to include in the $\mathrm{P}$ cell a hemidesmosome and site of neurofilament attachment not related to the wrappings. The separation between cells depicted here is greater than at chemical synapses described in the leech. The section was tilted $\pm 60^{\circ}$ to confirm that no cell processes lie between the $\mathrm{N}$ and $\mathrm{P}$ cells.

for the injury and for the denervation mechanisms, as described below.

One approach to distinguishing separate models is to use the observation illustrated in Figure 3 that an $l \mathrm{~N}$ cell within an isolated ganglion wraps targets on both sides of the ganglion with almost equal frequency. This contrasts with control preparations, in which the wrappings are in adjacent ganglia and only $16 \%$ of the $l \mathrm{~N}$ cell's axosomatic targets are situated contralaterally. $\mathrm{N}$-cell axons project to neighboring ganglia along ipsilateral connectives; thus, cutting only the ipsilateral connectives anterior and posterior to an $l \mathrm{~N}$ cell's ganglion will separate the cell from its usual targets in neighboring ganglia (Fig. 6).

If injuring the $l \mathrm{~N}$ cell or interrupting its connections with its targets causes sprouting, then the axotomized $l \mathrm{~N}$ cell will sprout, presumably on both sides of the ganglion as in the isolated ganglion, but the contralateral, uninjured $l \mathrm{~N}$ cell should not (Fig. $6 b$ ). In contrast, if target denervation causes sprouting, then both IN cells in the ganglion would be expected to sprout, but they should sprout principally ipsilateral to the cut connectives, where most denervated cells are situated (Fig. $6 a$ ). If injury of the targets is the trigger, then both $l \mathrm{~N}$ cells should sprout, wrapping only cells ipsilateral to the lesion, because the targets' axons project down ipsilateral connectives. In the experiments with isolated ganglia cited above, the $l \mathrm{~N}$ cells in ganglia adjacent to the isolated ganglion formed few axosomatic wrappings; thus, a
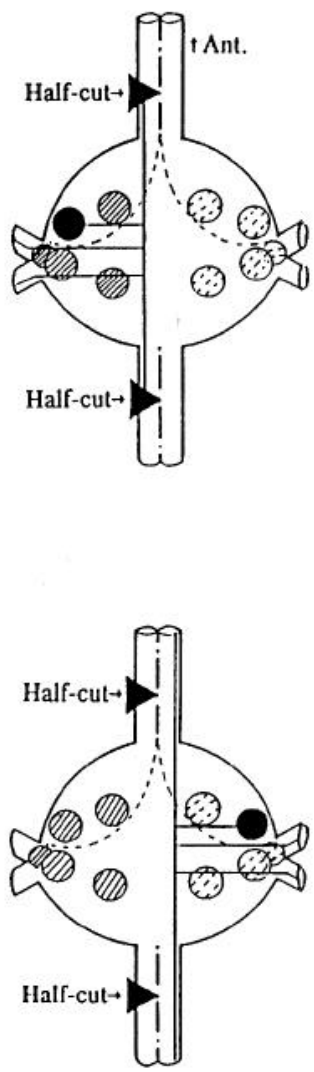

b
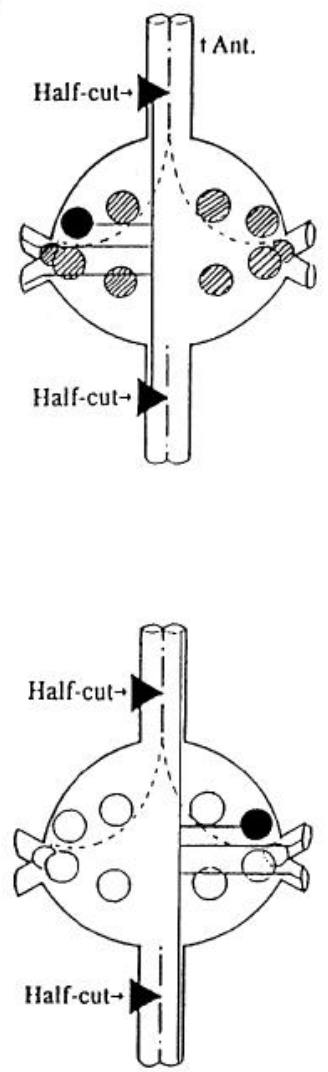

Figure 6. Patterns of cell wrappings predicted for denervation- or injury-induced sprouting. Cutting single connectives anterior and posterior to the ganglion could distinguish whether injury or denervation induces axosomatic wrappings. Ganglia in diagrams are shown halfisolated, with left connectives cut as indicated by solid triangles and injected $\mathbb{I N}$ cells in black. Wrapped cells are indicated with hatching, with hatching density in approximate proportion to the incidence of wrapping. Open circles represent unwrapped somata. $a$, Denervationtriggered sprouting might be expected to cause both $l \mathrm{~N}$ neurons to sprout, regardless of whether it was the directly injured (top) or intact (bottom) neuron; most wrapping would then be on the cut side (see Fig. 3 for expected distributions on the 2 sides). $b$, In contrast, with injurytriggered sprouting, only the injured (top) and not the intact $\mathrm{N}$ cell (bottom) might be expected to sprout; wrapped somata would be evenly distributed on both sides of the ganglion. Were both injury and denervation required together, only the injured $\mathrm{N}$ cell would sprout, and its targets would be mainly ipsilateral (as for black cell in top ganglion in a). In contrast, if either injury or denervation were sufficient to trigger sprouting, then both $\mathrm{N}$ cells in the ganglion should sprout. Ant, anterior.

injury either to the $l \mathrm{~N}$ cell or to the target is unlikely by itself to be significant.

Eleven ganglia were examined that had been isolated only on 1 side; the anterior and posterior connectives were cut so as to impede regeneration without injuring the contralateral connectives of the same ganglion either anteriorly or posteriorly (Fig. 7). Ten of the $11 l \mathrm{~N}$ cells $(91 \%)$ on the cut side sprouted and wrapped $13 \mathrm{P}$ or $\mathrm{N}$ cells and 1 Leydig cell. No other somata were wrapped. Twelve axosomatic wrappings (75\%) were ipsilateral to the cuts, while $4(25 \%)$ were contralateral. On average, the injured $l \mathrm{~N}$ cells sprouted 1.5 axosomatic contacts within the ganglion. Eight of the 11 uninjured $l \mathrm{~N}$ cells $(72 \%)$ in the halfisolated ganglia, cells that were contralateral to the cuts, sprouted wrappings exclusively on either $\mathrm{N}$ or P cells, $9(82 \%)$ on the cut 

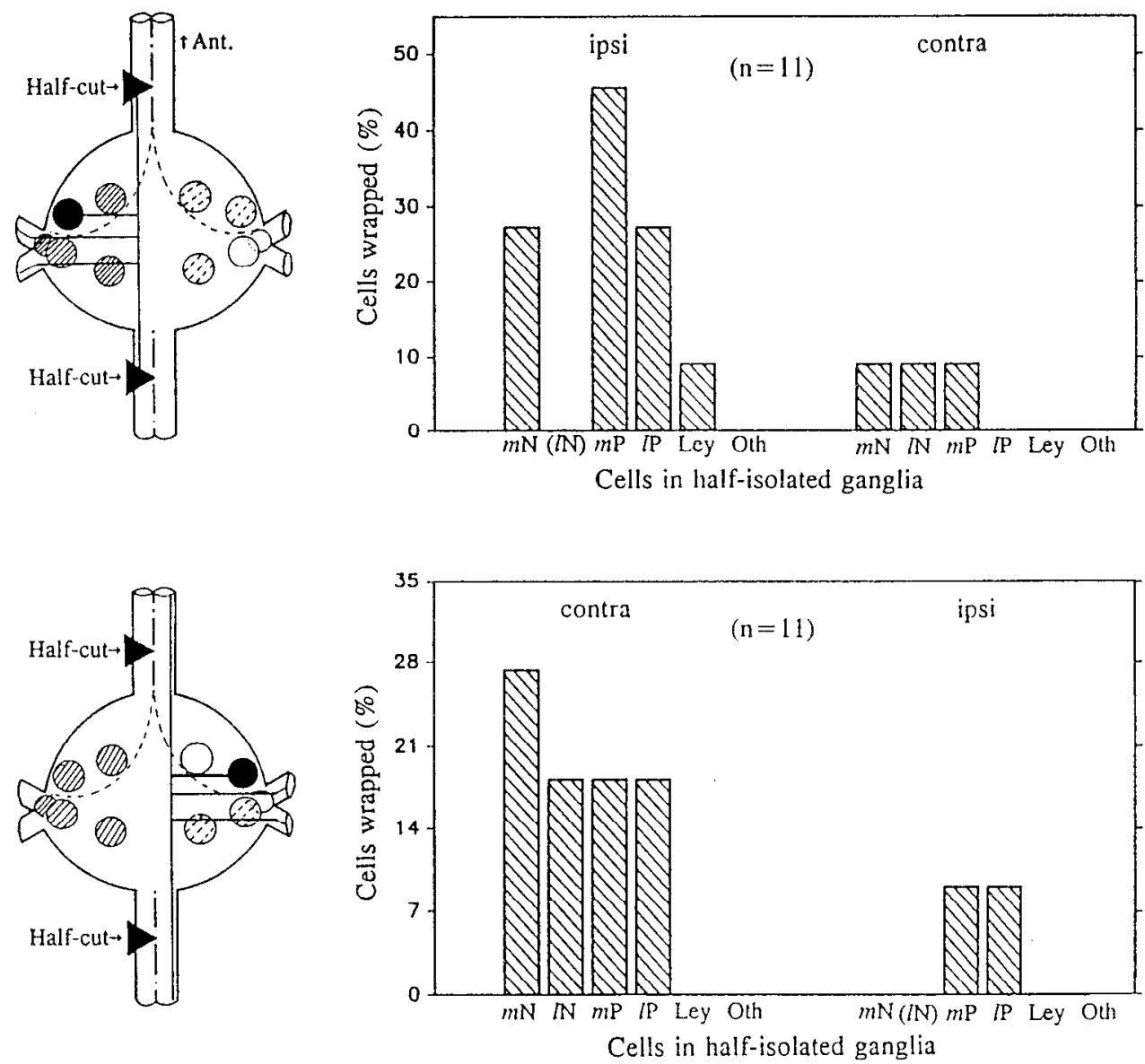

Figure 7. Denervated targets become wrapped by axons of injured and intact $l \mathrm{~N}$ cells in half-isolated ganglia. Diagrams at the left depict lesions on 1 side both anterior and posterior to the $\mathbb{N}$ cells' ganglion. Two to 4 months later, the injured (top) and intact (bottom) cells were each examined using separate markers. Injected $l \mathrm{~N}$ cells are depicted as solid circles, while hatching density is in approximate proportion to degree of wrapping. Open circles depict unwrapped somata. The distribution of somata wrapped by axons of injured $\mathbb{I N}$ cells, which sprouted to wrap an average of 1.3 cells per ganglion, is at the top right. The distribution of somala wrapped by intact $l \mathrm{~N}$ cells, which sprouted to wrap an average of 1.0 cell per ganglion, is on bottom right. Ant, anterior; Ley, Leydig cells; Oth, other cells. side and $2(18 \%)$ on the intact side of the half-isolated ganglia. Such intact $l \mathrm{~N}$ cells wrapped 1.0 somata, on average, within their ganglion.

This is the result expected if sprouting is triggered by denervation of the target. For comparison, about twice as many somata (2.5) were wrapped after complete isolation of ganglia, consistent with twice the denervation caused by cutting all 4 connectives. It is not clear whether the somewhat greater sprouting by $I N$ cells on the injured side, if significant, is an effect of injury, which could enhance sprouting, or whether there are more somata denervated in the proximity of the $l \mathrm{~N}$ cell ipsilateral to the crush, which might put that cell at an advantage in sprouting.

\section{Denervation without connective injury triggers sprouting}

The sprouting both of injured and of intact $I N$ cells in halfisolated ganglia was consistent with the hypothesis that denervation of $\mathrm{P}, \mathrm{N}$, and Leydig somata triggered sprouting. Of course, severing 1 of the paired connectives anterior and posterior to a ganglion is not a selective operation. A more direct test of the target-denervation hypothesis is to selectively kill the $\mathrm{N}$ cells in the anterior and posterior adjacent ganglia, which will denervate the $\mathrm{N}$ and $\mathrm{P}$ cells in the ganglion under investigation. The $4 \mathrm{~N}$ cells in both ganglia on either side of a central ganglion were selectively destroyed by intracellular injection of protease. Medial and lateral $\mathrm{N}$ cells both were selected for killing because both wrap similar somata in adjacent ganglia, and cutting the connectives interrupted projections from both types of $\mathrm{N}$ cells.
As with isolated and half-isolated ganglia, HRP and 6-CF were used to label separate $I \mathrm{~N}$ cells.

Fourteen of $16 l \mathrm{~N}$ cells $(88 \%)$ examined 2 months postoperatively had sprouted axosomatic wrappings in experimental ganglia. P, N, and Leydig somata, both ipsilateral and contralateral to the $l \mathrm{~N}$ cell, were wrapped with various frequencies of occurrence, as shown in Figure 8. A total of 40 somata were wrapped, for an average of 2.4 per $I N$ cell, which was nearly identical to the value of 2.5 somata observed for isolated ganglia. Thus, selective denervation was as effective as ganglion isolation in triggering sprouting of axosomatic wrappings.

A series of other ganglia were examined that had been half as denervated by killing $\mathrm{N}$ cells only in the ganglion anterior or posterior to the ganglion under observation. For $23 / \mathrm{N}$ cells examined in these ganglia, there were 22 somata wrapped for an average of 1.0 soma wrapped per cell. This value, approximately half the sprouting of cells in ganglia twice as denervated by cutting or killing anteriorly and posteriorly, is comparable to sprouting when only left or right connectives were cut anteriorly and posteriorly.

\section{Interaction between medial and lateral $N$ cells}

Killing $l \mathrm{~N}$ and $m \mathrm{~N}$ cells together in ganglia 10 and 12 was sufficient to prompt sprouting of the $I \mathrm{~N}$ cells in ganglion 11 , but conceivably, it was not necessary to destroy $m \mathrm{~N}$ cells to obtain sprouting of the $I \mathrm{~N}$ cells in their own ganglion. The $m \mathrm{~N}$ cells' wrappings might not interact with those of $l \mathrm{~N}$ cells. Experiments were performed in which either only $l \mathrm{~N}$ cells were injected with 
Figure 8 . Selective denervation by killing $N$ cells in adjacent ganglia causes glion. In the left portion of the diagram, crossed-out circles illustrate positions of $4 \mathrm{~N}$ cells killed by intracellular injection of protease in ganglia anterior and posterior to the experimental ganglion. Two to 4 months later, both $I \mathrm{~N}$ cells in the middle ganglion (one of those injected, depicted by a solid circle), which were uninjured, were examined for sprouting within their ganglion. Wrapped cells are hatched, as in other figures. The graph shows the distribution of somata wrapped by the axons of the $l \mathrm{~N}$ cells within their ganglion. Ant, anterior; Ley, Leydig cells; Oth, other cells. $\mathrm{N}$ cells to sprout within their own gan-
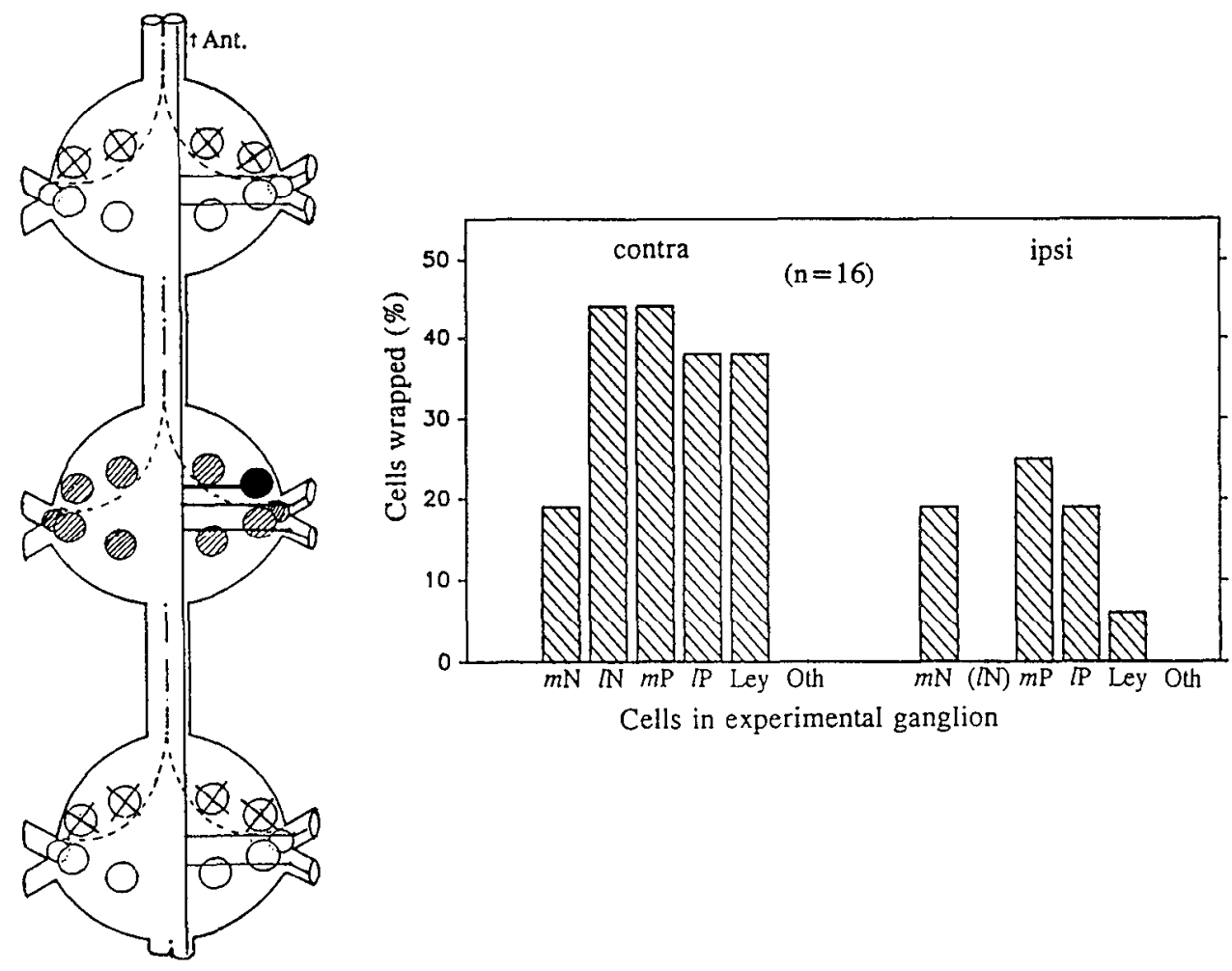

protease and destroyed or only $m \mathrm{~N}$ cells were destroyed to test for a possible interaction between the cell types.

In 4 animals, only the $4 \mathrm{mN}$ cells in ganglia 10 and 12 were destroyed with protease. Four months later, the $2 \mathrm{IN}$ cells in ganglion 11 in each of the 4 animals were examined. Only 1 of 8 cells examined appeared to have sprouted, and it wrapped just 1 cell in a single ganglion. This was the same low incidence of sprouting as after killing the Retzius cells (see below) and was judged to be nonspecific and probably insignificant.

Paradoxically, 2-6 months after killing the $4 \mathrm{IN}$ cells in ganglia 10 and 12 (8 animals), 7 of $15 / \mathrm{N}$ cells in ganglion 11 sprouted to wrap only 1 soma on average. If this difference from the 2.5 wrappings that sprouted after killing $m \mathrm{~N}$ and $\mathrm{lN}$ cells in neighboring ganglia is significant, it would suggest that, in the absence of $l \mathrm{~N}$ cells, the $m \mathrm{~N}$ cell might assume some $\mathbb{N}$ function. This is consistent with another result, presented above. After all $4 \mathrm{~N}$ cells were killed in a single ganglion, either posteriorly or anteriorly, the $l \mathrm{~N}$ cell under study sprouted to wrap only 1.0 cell, on average, in its own ganglion.

As controls, to test whether simply killing major cells in adjacent ganglia caused sprouting, Retzius cells rather than $\mathrm{N}$ cells were killed by protease injection. Ordinarily, Retzius cells synapse within adjacent ganglia, but do not wrap somata wrapped by $\mathrm{N}$ cells. Fourteen $l \mathrm{~N}$ cells were examined 2 months postoperatively. Only 2 cells, a Leydig and an $m$ P cell, were wrapped within their own ganglion. While the operation may thus have triggered a low level of sprouting, the amount of sprouting was essentially within the range of controls.

Thus, denervation of potential targets within the $l \mathrm{~N}$ cell's ganglion caused the cell to sprout and appeared to be proportional to the extent of denervation. Because $l \mathrm{~N}$ cells sprouted as much without injury as with it, injury was not needed for sprouting. The major factor producing sprouting was target denervation and not injury.

\section{Discussion}

The nature of axosomatic contacts

The axosomatic wrappings are appealing for investigation because they are a set of specific contacts that can be readily seen using a light microscope. Thus, one can rapidly ascertain not only which cells are wrapped, but also which are not. Even the finest axons that form baskets are detectable with light microscopy using 6-CF or HRP staining, as confirmed by electron microscopy. Electron microscopy has also shown that axosomatic wrappings are sites of contact between the $l \mathrm{~N}$ cell's axon and target soma. Physiological recordings have shown indirectly, by stripping cells of axosomatic wrappings, that the wrappings are excitatory (French and Muller, 1986). But, it is difficult experimentally to isolate input to the soma because the axons coil around the initial segment of the cell en route to wrapping the soma. Interestingly, after the somata of $\mathrm{P}$ and $\mathrm{N}$ cells have been desheathed, and thus stripped of their axosomatic wrappings (Muller et al., 1978), they are sensitive to focally applied transmitters (Sargent et al., 1977). It would be useful to know more concerning the physiology of the normal and sprouted contacts, including their functional role, but it is not essential for the present analysis.

\section{Innervation from adjacent ganglia blocks cells from making axosomatic contacts within their ganglion}

Why do axons of the $I N$ cell wrap P, N, and Leydig cells in neighboring ganglia, but not the same types of somata that appear to be equally accessible in its own ganglion? This question, which led to the present experiments, is an aspect of a more general problem concerning the formation of specific connections between neurons. The question seems appropriate to address using adult leeches because axosomatic contacts regenerate accurately, and in that sense, specifically, in adults. Experiments 
with isolated ganglia showed that $l \mathrm{~N}$ cells can wrap $\mathrm{P}, \mathrm{N}$, and Leydig cells in their own ganglion and are thus not inherently unable to do so. Furthermore, the $\mathrm{N}$ cells remain selective in wrapping $\mathrm{P}, \mathrm{N}$, and Leydig cells, but not other cells. The basis of this selectivity is unknown and was not addressed in the present study.

It is interesting that there was little or no sprouting by 2-4 months in ganglia adjacent to the isolated ganglion, because targets were partially denervated, and $l \mathrm{~N}$ cells were injured in those adjacent ganglia. At later times, however, some $I \mathrm{~N}$ cells in those ganglia sprouted wrappings. The delay in sprouting might have been related to an increased distance of the ganglia from the lesion, for the cuts were made close to the isolated ganglion, so that the cut axons wrapping somata in the isolated ganglion were short from the cut end to the wrappings, but those wrapping somata in adjacent ganglia were several times longer. Axon segments in the leech may survive weeks or months (Mason and Muller, 1983), and there is some indication that degeneration of the severed $\mathrm{N}$-cell axons begins at the cut end and progresses distally, as in other systems (Carbonetto and Muller, 1982). Thus, the long, severed axons extending the length of the connectives from the cut to ganglia adjacent to the isolated ganglion may have been slower to degenerate their wrappings. Delay might also have resulted from incomplete dencrvation of somata, because only a single pair of connectives leading to adjacent ganglia was severed. However, such delay was not noted in ganglia with connectives cut only on either the left or the right side, where within 2 months, there was some sprouting to wrap partially denervated somata on the intact side.

After only 1 connective anterior and 1 posterior to the ganglion on just 1 side (e.g., both on the left) were cut, the pattern of sprouting observed was that expected for denervation of the targets rather than injury either to targets or to the $I N$ cell. In particular, the $l \mathrm{~N}$ cell on the uninjured side sprouted to wrap targets. In separate experiments, selective denervation by destroying the $4 \mathrm{~N}$ cells in ganglia adjacent to a central ganglion provided independent confirmation that denervation causes sprouting.

A simple interpretation of these results is that $\mathrm{N}$ cells can wrap particular somata in their own ganglion, but they ordinarily do not because they are excluded from so doing by $\mathrm{N}$ cells in adjacent ganglia. The effect is that of a lopsided competition, with axons originating in other ganglia at an extreme competitive advantage. There is, at present, no information as to what confers the advantage, but the exclusion seems not to be absolute, because sprouting occurs after partial denervation within the ganglion.

\section{Target denervation versus injury-induced sprouting}

The present result that $\mathrm{N}$ cells sprout to innervate denervated targets is similar to previous findings for the same neurons in the periphery, where electrophysiological mapping of receptive fields in the skin indicated that destruction of medial and lateral $\mathrm{N}$ cells on one side promoted expansion of $\mathrm{N}$-cell receptive fields from the other side (Blackshaw et al., 1982b). Although there was no anatomical evidence that the physiologically recorded expansion reflected sprouting, it now seems more likely, particularly because the interaction between $\mathbb{N}$ and $m \mathrm{~N}$ cells was superficially similar in the CNS and periphery. One difference, however, is that $m \mathrm{~N}$ cells often make a limited number of somatic wrappings within their own ganglion, and those wrappings may be present on somata that are wrapped by the $l \mathrm{~N}$ cell from the next ganglion. It is well established, however, that there are broad differences between $l \mathrm{~N}$ and $m \mathrm{~N}$ cells in their pharmacological (Johansen et al., 1984b) and antigenic (Johansen et al., 1984a) properties, as well as differences in peripheral receptive fields (Blackshaw et al., 1982a) and transmitter sensitivities (Sargent et al., 1977).

The peripheral and central sprouting resembles, in some regards, that in other systems, such as sprouted receptive fields in salamander skin (Diamond et al., 1976; Scott et al., 1981) and sprouting within the brain (Raisman, 1969; Yoon, 1972; Cotman et al., 1981). Tsukahara's classic study of sprouting in the red nucleus (Tsukahara et al., 1975) is of particular interest because inputs were added to or redistributed on the target cell.

The results reported here complement those of Blackshaw and collaborators, who studied $\mathrm{N}$ cells and other sensory neurons after cutting or crushing roots (Bannatyne et al., 1989). Axosomatic wrappings by $\mathrm{N}$ cells whose large axons in the roots had been crushed or cut suggested that injury alone might trigger sprouting. Unfortunately, no distinction was made between $m \mathrm{~N}$ cells, which typically wrap somata in their own ganglion, and $\mathbb{N}$ cells, which do not. However, it is conceivable that, with sufficient injury to the $l \mathrm{~N}$ cell, such as severing its largest axons as occurs when the roots are damaged, the cell might be induced to sprout axosomatic baskets within its ganglion. In the previous experiments (Bannatyne et al., 1989), the axons of the wrapped targets were evidently also severed.

\section{Formation of selective connections}

The sprouting of axosomatic contacts to wrap specific targets may be compared with the development of selective connections in vertebrates. The $\mathrm{N}$ cells will sprout abnormal wrappings in response to partial denervation of novel targets despite innervating their usual targets. This is, in some respects, similar to sprouting in the vertebrate visual system during development (Miller and Lund, 1975) and regeneration (Yoon, 1972), though the mapping between retina and target is not rigid. In contrast, studies of neuromuscular connections in amphibians and birds show that embryonic motoneurons will innervate incorrect targets only if the usual targets are missing, and regenerating motor axons in amphibians preserve some selectivity, even in the absence of competition (Farel and Wray, 1989). Target innervation is also important for the $\mathbf{S}$ cell in the leech, whose intact axon can sprout when its synaptic target is selectively destroyed (Scott and Muller, 1980).

One interpretation of some of the results is that, for vertebrate neurons and leech $\mathrm{N}$ cells, there is a hierarchy of target suitability. Although for $\mathrm{N}$ cells, target denervation alone is sufficient to induce sprouting, that sprouting is highly specific. Therefore, one could ask whether alternative cells might be wrapped if $\mathrm{N}$ - and $\mathrm{P}$-cell targets are removed. Overall, the results show that there is a matching between N-cell axons and their axosomatic targets, but that the final pattern of wrappings is determined by an exclusion or unequal competition in which axons from adjacent ganglia prevail.

\section{References}

Bannatyne BA, Blackshaw SE, McGregor M (1989) New growth elicited in adult leech mechanosensory neurones by peripheral axon damage. J Exp Biol 143:419-434.

Blackshaw SE, Nicholls JG, Parnas I (1982a) Physiological responses, receptive fields and terminal arborizations of nociceptive cells in the leech. J Physiol (Lond) 326:251-260.

Blackshaw SE, Nicholls JG, Parnas I (1982b) Expanded receptive fields 
of cutaneous mechanoreceptor cells after single neurone deletion in leech central nervous system. J Physiol (Lond) 326:261-268.

Bowling D, Nicholls J, Parnas I (1978) Destruction of a single cell in the central nervous system of the leech as a means of analysing its connexions and functional role. J Physiol (Lond) 282:169-180.

Carbonetto S, Muller KJ (1982) Nerve fiber growth and the cellular response to axotomy. Curr Top Dev Biol 17:33-76.

Cotman CW, Nieto-Sampedro M, Harris EW (1981) Synapse replacement in the nervous system of adult vertebrates. Physiol Rev 61:684 784.

Diamond J, Cooper E, Turner C, Macintyre L (1976) Trophic regulation of nerve sprouting. Science 193:371-377.

Elliot EJ, Muller KJ (1983) Sprouting and regeneration of sensory axons after destruction of ensheathing glial cells in the leech CNS. J Neurosci 3:1994-2006.

Farel PB, Wray SE (1989) Regenerative specificity of motor axons when reinnervation is partially suppressed. J Neurobiol 20:69-80.

French KA, Muller KJ (1986) Regeneration of a distinctive set of axosomatic contacts in the leech central nervous system. J Neurosci $6: 318-324$

Gaze RM (1970) The formation of nerve connections. New York: Academic.

Grinnell AD, Letinsky MS, Rheuben MB (1979) Competitive interaction between foreign nerves innervating frog skeletal muscle. J Physiol (Lond) 289:241-262.

Harris WA (1980) The effects of eliminating impulse activity on the development of the retinotectal projection in salamanders. J Comp Neurol 194:303-317.

Harrison RG (1904) An experimental study of the relation of the nervous system to the developing musculature in the embryo of the frog. Am J Anat 3:197-220.

Hubel DH, Wiesel TN, LeVay S (1977) Plasticity of ocular dominance columns in the monkey striate cortex. Philos Trans R Soc Lond [Biol] 278:377-409.

Jacobs GA, Miller JP, Murphey RK (1986) Integrative mechanisms controlling directional sensitivity of an identified sensory interneuron. J Neurosci 6:2298-2311.

Jansen JKS, Nicholls JG (1972) Regeneration and changes in synaptic connections between individual nerve cells in the central nervous system of the leech. Proc Natl Acad Sci USA 69:636-639.

Jansen JKS, Muller KJ, Nicholls JG (1974) Persistent modification of synaptic interactions between sensory and motor nerve cells following discrete lesions in the central nervous system of the leech. $J$ Physiol (Lond) 242:289-305.

Johansen J, Hockfield S, McKay RDG (1984a) Distribution and morphology of nociceptive cells in the CNS of three species of leeches. J Comp Neurol 226:263-273.

Johansen J, Yang J, Kleinhaus AL (1984b) Actions of procaine on specific nociceptive cells in leech central nervous system. J Neurosci 4:1253-1261.

Kandel ER (1976) Cellular basis of behavior: an introduction to behavioral neurobiology. San Francisco: Freeman.

Landmesser LT (1980) The generation of neuromuscular specificity. Annu Rev Neurosci 3:279-302.
Macagno ER, Lopresti V, Levinthal C (1973) Structure and development of neuronal connections in isogenic organisms: variations and similarities in the optic system of Daphnia magna. Proc Natl Acad Sci USA 70:57-61.

Mason A, Muller KJ (1983) Regeneration and plasticity of neuronal connections in the leech. Trends Neurosci 6:172-176.

McGlade-McCulloh E, Morrissey AM, Norona F, Muller KJ (1989) Individual microglia move rapidly and directly to nerve lesions in the leech central nervous system. Proc Natl Acad Sci USA 86:10931097.

Miller BF, Lund RD (1975) The pattern of retinotectal connections in albino rats can be modified by fetal surgery. Brain Res 91:119125.

Muller KJ, Carbonetto S (1979) The morphological and physiological properties of a regenerating synapse in the CNS of the leech. J Comp Neurol 185:485-516.

Muller KJ, McMahan UJ (1976) The shapes of sensory and motor neurones and the distribution of thcir synapses in ganglia of the leech: a study using intracellular injection of horseradish peroxidase. Proc R Soc Lond [Biol] 194:481-499.

Muller KJ, Scott SA, Thomas BE (1978) Specific associations between sensory cells. Carnegie Inst Wash Yrbk 77:69-70.

Muller KJ, Nicholls JG, Stent GS (1981) Neurobiology of the leech. Cold Spring Harbor, NY: Cold Spring Harbor Laboratory.

Pumplin DW, Muller KJ (1983) Distinctions between gap junctions and sites of intermediate filament attachment in the leech C.N.S. J Neurocytol 12:805-815.

Raisman G (1969) Neuronal plasticity in the septal nuclei of the adult rat. Brain Res 14:25-48.

Rakic P (1976) Prenatal genesis of connections subserving ocular dominance in the rhesus monkey. Nature 261:467-471.

Sargent PB, Yau KW, Nicholls JG (1977) Extrasynaptic rcceptors on cell bodies of neurons in central nervous system of the leech. J Neurophysiol 40:446-452.

Scolt SA, Muller KJ (1980) Synapse regeneration and signals for directed axonal growth in the C.N.S. of the leech. Dev Biol 80:345363.

Scott SA, Macintyre L, Diamond J (1981) Competitive reinnervation of salamander skin by regenerating and intact mechanosensory nerves. Proc R Soc Lond [Bioll 211:501-511.

Tsukahara N, Hultborn H, Murakami F, Fujito Y (1975) Electrophysiological study of formation of new synapses and collateral sprouting in red necleus neurons after partial denervation. J Neurophysiol 38: 1359-1372.

Wallace BG, Adal MN, Nicholls JG (1977) Sprouting and regeneration of synaptic connexions by sensory ncurones in lecch ganglia maintained in culture. Proc R Soc Lond [Biol] 199:567-585.

White JG, Southgate E, Thompson JN, Brenner S (1976) The structure of the ventral nerve cord of Caenorhabditis elegans. Philos Trans $\mathrm{R}$ Soc Lond [Biol] 275:327-348.

Yoon M (1972) Reversibility of the reorganization of retinotectal projection in goldtish. Exp Neurol 35:565-577. 